\title{
PENERAPAN MODEL PEMBELAJARAN INTERAKTIF PADA MATA PELAJARAN IPA DI SD
}

\author{
Oleh: Suprayetkti *
}

\section{Abstrak}

Penelitian ini bertujuan untuk untuk menerapkan model pembelajaran interaktif pada pelajaran IPA dengan kerja kelompok sebagai suatu upaya perbaikan dan peningkatan proses pembelajaran. Metode penelitian menggunakan Penelitian Tindakan Kelas (PTK) yang dilaksanakan dengan mengikuti prosedur penelitian berdasarkan prinsip Kemmis S, MC Toggar $R$ (1988) yang mencakup kegiatan perencanaan (planning), tindakan (action), observasi (observation), refleksi (reflection) atau evaluasi. Keempat kegiatan ini berlangsung secara berulang dalam bentuk siklus. Penelitian ini dilakukan dengan cara berkolaborasi antara dosen LPTK (FKIP-UT) dengan guru SD Negeri Jakarta Timur. Hasil penelitian menunjukkan bahwa (1) kinerja belajar siswa meningkat setelah belajar IPA menggunakan model pembelajaran interaktif. Siswa sangat antusias berdiskusi yaitu tampak dari berbagai upaya yang dilakukan untuk menjawab dan menemukan informasi, serta saling berebut mengemukakan informasi tentang topik bahasan. Setelah dilakukan pembagian tugas kelompok, siswa bekerja sesuai dengan tugasnya masing-masing; dan (2) prestasi belajar siswa meningkat setelah mengalami pembelajaran interaktif dengan kerja kelompok. Berdasarkan nilai yang diperoleh siswa dapat disimpulkan bahwa model pembelajaran interaktif dengan kerja kelompok dapat digunakan pada penelitian tindakan kelas.

Kata Kunci: $\quad$ model pembelajaran interaktif, penelitian tindakan kelas, IPA, SD.

\section{PENDAHULUAN}

A. Meningkatkan mutu pendidikan adalah menjadi tanggungjawab semua pihak yang terlibat dalam pendidikan terutama bagi guru SD, yang merupakan ujung tombak dalam pendidikan dasar. Guru SD adalah orang yang paling berperan dalam menciptakan sumber daya manusia yang berkualitas yang dapat bersaing di jaman pesatnya perkembangan teknologi. Guru SD dalam setiap pembelajaran selalu menggunakan pendekatan, strategi dan metode pembelajaran yang dapat memudahkan siswa memahami materi yang diajarkannya, namun masih sering terdengar keluhan dari para guru di lapangan tentang materi pelajaran yang terlalu banyak dan keluhan kekurangan waktu untuk mengajarkannya semua.

Menurut pengamatan penulis, dalam pelaksanaan pembelajaran di kelas penggunaan model pembelajaran yang bervariatif masih sangat rendah dan guru cenderung menggunakan model konvesional pada setiap pembelajaran yang dilakukannya. Hal ini mungkin disebabkan kurangnya penguasaan guru terhadap model-model pembelajaran yang ada, padahal penguasaan terhadap model-model pembelajaran sangat

*) Dra. Suprayetkti, M.Pd, adalah Dosen pada Program Studi Teknologi Pendidikan, Fakultas IImu Pendidikan, Universitas Negeri Jakarta. 
diperlukan untuk meningkatkan kemampuan profesional guru, dan sangat sesuai dengan kurikulum berbasis kompetensi.

Kurikulum berbasis kompetensi yang mulai diberlakukan di sekolah dasar bertujuan untuk menghasilkan lulusan yang kompeten dan cerdas sehingga dapat melanjutkan pendidikan ke jenjang yang lebih tinggi. Hal ini hanya dapat tercapai apabila proses pembelajaran yang berlangsung mampu mengembangkan seluruh potensi yang dimiliki siswa, dan siswa terlibat langsung dalam pembelajaran IPA. Disamping itu kurikulum berbasis kompetensi memberi kemudahan kepada guru dalam menyajikan pengalaman belajar, sesuai dengan prinsip belajar sepanjang hidup yang mengacu pada empat pilar pendidikan universal, yaitu belajar untuk mengetahui (learning to know), belajar dengan melakukan (learning to do), belajar untuk hidup dalam kebersamaan (learning to live together), dan belajar menjadi diri sendiri (learning to be).

Untuk itu guru perlu meningkatkan mutu pembelajarannya, dimulai dengan rancangan pembelajaran yang baik dengan memperhatikan tujuan, karakteristik siswa, materi yang diajarkan, dan sumber belajar yang tersedia. Kenyataannya masih banyak ditemui proses pembelajaran yang kurang berkualitas, tidak efisien dan kurang mempunyai daya tarik, bahkan cenderung membosankan, sehingga hasil belajar yang dicapai tidak optimal. Hal ini dapat dilihat dari hasil belajar IPA siswa kelas 5 di SDN Jakarta Timuryang dipaparkan pada tabel berikut.

Tabel 1. Nilai rapor untuk mata pelajaran IPA Tahun Ajaran 1998/1999 sampai dengan 2003/2004 SDN

Pagi Jakarta Timur

\begin{tabular}{|c|c|c|c|}
\hline $\begin{array}{c}\text { Tahun } \\
\text { Ajaran }\end{array}$ & $\begin{array}{c}\text { Nilai } \\
\text { Tertinggi }\end{array}$ & $\begin{array}{c}\text { Nilai } \\
\text { Terendah }\end{array}$ & $\begin{array}{c}\text { Nilai } \\
\text { Rata-Rata }\end{array}$ \\
\hline $1998 / 1999$ & 6,34 & 3,78 & 5,06 \\
$1999 / 2000$ & 7,26 & 4,26 & 5,76 \\
$2000 / 2001$ & 6,82 & 3,96 & 5,39 \\
$2001 / 2002$ & 7,12 & 4,12 & 5,62 \\
$2002 / 2003$ & 7,36 & 3,42 & 5,39 \\
$2003 / 2004$ & 6,92 & 4,08 & 5,00 \\
\hline
\end{tabular}

Rendahnya perolehan hasil belajar mata pelajaran IPA di SDN Jakarta Timur munjukkan adanya indikasi terhadap rendahnya kinerja belajar siswa dan kemampuan guru dalam mengelola pembelajaran yang berkualitas. Untuk mengetahui mengapa prestasi siswa tidak seperti yang diharapkan, tentu guru perlu merefleksi diri untuk dapat mengetahui faktor-faktor penyebab ketidakberhasilan siswa dalam pelajaran IPA. Sebagai guru yang baik dan profesional, permasalahan ini tentu perlu ditanggulangi dengan segera.

Berdasarkan hal tersebut diatas, penerapan model pembelajaran interaktif menjadi alternatif untuk dapat meningkatkan prestasi belajar siswa dalam mata pelajaran IPA.

Penelitian ini dilakukan peneliti yang bertugas sebagai tenaga dosen FKIP-UT dengan berkolaborasi dengan guru-guru SD di SDN Jakarta Timur. Dengan berlolaborasi ini, diharapkan kemampuan profesional guru dalam merancang model pembelajaran akan lebih baik lagi dan dapat menerapkan model pembelajaran yang lebih bervariatif. Disamping itu kolaborasi ini dapat meningkatkan kemampuan guru dalam merefleksi diri terhadap kinerja yang telah dilakukannya, sehingga dapat melakukan perubahan dan perbaikan kualitas pembelajaran dan mengelola proses pembelajaran yang lebih terpusat pada siswa.

Model pembelajaran interaktif sering dikenal dengan nama pendekatan pertanyaan anak. Model ini dirancang agar siswa akan bertanya dan kemudian menemukan jawaban pertanyaan mereka sendiri (Faire \& Cosgrove dalam Harlen, 1992). Meskipun anak-anak mengajukan pertanyaan dalam kegiatan bebas, 
pertanyaan-pertanyaan tersebut akan terlalu melebar dan seringkali kabur sehingga kurang terfokus. Guru perlu mengambil langkah khusus untuk mengumpulkan, memilah, dan mengubah pertanyaan-pertanyaan tersebut ke dalam kegiatan khusus. Pembelajaran interaktif merinci langkah-langkah ini dan menampilkan suatu struktur untuk suatu pelajaran IPA yang melibatkan pengumpulan dan pertimbangan terhadap pertanyaan-pertanyaan siswa sebagai pusatnya (Harlen, 1992:48-50)

Salah satu kebaikan dari model pembelajaran interaktif adalah bahwa siswa belajar mengajukan pertanyaan, mencoba merumuskan pertanyaan, dan mencoba menemukan jawaban terhadap pertanyaannya sendiri dengan melakukan kegiatan observasi (penyelidikan). Dengan cara seperti itu siswa atau anak menjadi kritis dan aktif belajar.

\section{B. PERUMUSAN MASALAH}

Berdasarkan latar belakang masalah yang telah diuraikan sebelumnya, maka rumusan masalah yang diajukan dalam penelitian ini adalah sebgai berikut.

1. Bagaimana desain model pembelajaran interaktif dengan kerja kelompok dalam pembelajaran IPA di SD?

2. Bagaimana menerapkan model pembelajaran interaktif dengan kerja kelompok dalam pembelajaran IPA di SD?

3. Bagaimana kinerja belajar siswa dalam pembelajaran dengan menggunakan model pembelajaran interaktif dengan kerja kelompok?

4. Apakah dengan kerja kelompok dapat memperbaiki dan meningkatkan kinerja belajar siswa dalam menggunakan model pembelajaran interaktif dengan kerja kelompok?

5. Bagaimana kreaktivitas siswa dalam pembelajaran IPA yang menggunakan model pembelajaran interaktif dengan kerja kelompok?

6. Kendala yang dihadapi dalam pembelajaran interaktif dengan kerja kelompok?

\section{CARA PEMECAHAN MASALAH}

Permasalahan rendahnya hasil belajar IPA di SDN Jakarta Timur perlu segera ditanggulangi, dan guru perlu melakukan refleksi atas kinerjanya selama perolehan hasil belajar IPA masih dapat ditingkatkan lebih tinggi lagi, apabila kreaktifitas siswa dalam pembelajaran juga tinggi. Hasil penelitian mengungkapkan bahawa tingkat kreatifitas siswa saat penelitian dilaksanakan masih rendah, kinerja siswa menunjukkan fenomena sebagai berikut guru jarang membimbing siswa dalam diskusi tentang topik-topik IPA, guru jarang memberikan pertanyaan kepada siswa baik secara individual maupun secara klasikal. Siswa tidak berani bertanya kepada guru karena guru kurang memotivasi siswa agar berani bertanya apabila ada masalah/materi yang tidak/kurang dimengerti. Pembelajaran yang ada lebih terpusat pada guru, bukan kepada siswa. Hal ini tidak dapat dibiarkan begitu saja, apalagi dengan diberlakukannya kurikulum berbasis kompetensi yang mengisyaratkan pembelajaran harus dapat mengembang-kan semua potensi yang dimiliki siswa. Hal ini dapat tercapai apbila kinerja belajar siswa ditingkatkan, sehingga guru hanya berperan sebagai fasiltator, motivator dan organisator.

Berdasarkan hal tersebut diatas, dengan demikian untuk memperbaiki dan meningkatkan kualitas pembelajaran IPA di SD, menerapkan model pembelajaran interaktif sebagai alternatif untuk dapat meningkatkan perolehan hasil belajar IPA, dapat lebih optimal lagi apabila dilakukan melalui kerja kelompok. Rencana penerapan model tersebut dapat dilihat pada skema berikut.

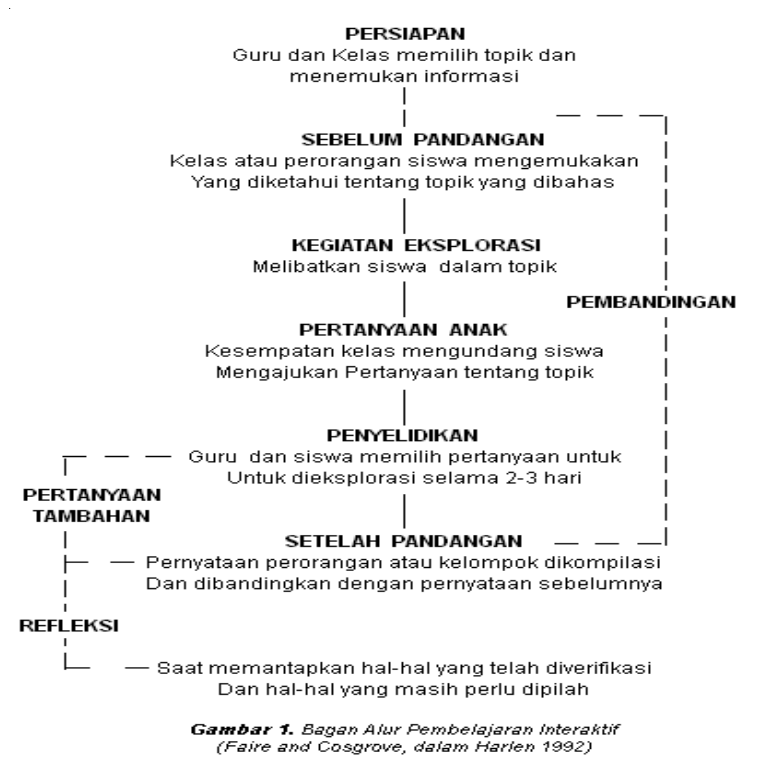




\section{TUJUAN PENELITIAN}

Secara umum tujuan penelitian ini adalah untuk menerapkan model pembelajaran interaktif pada pelajaran IPA dengan kerja kelompok, sebagai suatu upaya perbaikan dan peningkatan proses pembelajaran.

Secara khusus tujuan penelitian adalah sebagai berikut.

1. Mengetahui kemampuan guru mendesain model pembelajaran interaktif pada pelajaran IPA dengan kerja kelompok

2. Menerapkan model pembelajaran interaktif pada pelajaran IPA di SD dengan kerja kelompok

3. Meningkatkan kinerja belajar siswa dalam pembelajaran dengan menggunakan model pembelajaran interaktif dengan kerja kelompok

4. Mengetahui apakah kerja kelompok dapat memperbaiki dan meningkatkan kinerja belajar siswa dalam penerapan model pembelajaran interaktif

5. Meningkatkan kreativitas siswa dalam pembelajaran IPA yang menggunakan model pembelajaran interaktif dengan kerja kelompok.

6. Mengetahui kendala yang dihadapi dalam menerapkan model pembelajaran interaktif dengan kerja kelompok

7. Solusi yang dilakukan guru dalam mengatasi kendala dalam menerapkan model pembelajaran interaktif dengan kerja kelompok

\section{E. KONTRIBUSI HASIL PENELITIAN}

Bagi siswa pembelajaran interaktif memberikan pengalaman baru dan diharapkan memberikan kontribusi terhadap peningkatan belajarnya. Siswa memiliki kesadaran bahwa proses pembelajaran adalah dalam rangka mengembangkan potensi dirinya, karena itu keberhasilan pembelajaran sangat ditentukan oleh siswa. Disamping itu, melalui penelitian ini siswa terlatih untuk dapat memecahkan masalah dengan pendekatan ilmiah dan siswa didorong aktif secara fisik, mental, dan emosi dalam pembelajaran.

Bagi guru, penelitian ini diharapkan dapat meningkatkan kemampuan profesional, dan pembelajaran interaktif menjadi alternative pembelajaran IPA untuk meningkatkan prestasi siswa. Memberikan kesadaran guru untuk memperbaiki dan meningkatkan kualitas pembelajaran yang disesuaikan dengan tujuan, materi, karakteristik siswa, dan kondisi pembelajaran. Guru mempunyai kemampuan dalam merancang model pembelajaran interaktif yang merupakan hal baru bagi guru, dan menerapkannya dalam pembelajaran IPA. Dengan penelitian ini, kemampuan guru mengaktifkan siswa dan memusatkan pembelajaran pada pengembangan potensi diri siswa juga meningkat, sehingga pembelajaran lebih menarik, bermakna, menyenangkan, dan mempunyai daya tarik. Disamping itu penelitian ini dapat memperkaya pengalaman guru dalam melakukan perbaikan dan meningkatkan kualitas pembelajaran dengan refleksi diri atas kinerjanya melalui PTK.

Bagi kepala sekolah penelitian ini dapat dijadikan masukan untuk kebijakan dalam upaya meningkatkan proses belajar mengajar (PBM) dan meningkatkan prestasi belajar siswa serta perlunya kerjasama yang baik antar guru dan antara guru dengan kepala sekolah.

\section{KAJIAN PUSTAKA}

Ilmu Pengetahuan Alam di Sekolah Dasar adalah program untuk menanamkan dan mengembangkan pengetahuan keterampilan, sikap dan nilai ilmiah pada siswa serta rasa mencintai dan menghargai kebesaran Tuhan Yang Maha Esa. Tujuan IPA secara umum membantu agar siswa memahami konsepkonsep IPA dan keterkaitannya dengan kehidupan sehari-hari. Memiliki keterampilan untuk mengembangkan pengetahuan tentang alam sekitar maupun menerapkan berbagai konsep IPA untuk menjelaskan gejala-gejala alam yang harus dibuktikan kebenarannya di laboratorium, dengan demikian IPA tidak saja sebagai produk tetapi juga sebagai proses. Untuk itu ada tiga hal yang berkaitan dengan sasaran IPA di Sekolah Dasar adalah sebagai berikut. (1) IPA tidak semata berorientasi kepada hasil tetapi juga proses. (2) Sasaran pembelajaran IPA harus utuh menyeluruh dan (3) pembelajaran IPA akan lebih berarti apabila dilakukan secara berkesinambungan dan melibatkan siswa secara aktif. 


\section{A. Penelitian Tindakan Kelas (PTK)}

Seringkali kita mendengar kata penelitian, yang merupakan terjemahan dari bahasa Inggris : research, yang berarti kegiatan pencaharian atau ekspolrasi untuk menemukan jawaban dari masalah yang menjadi bidang kajian. Adapun yang dimaksud dengan Penelitian Tindakan Kelas (PTK) atau classroom action research, yaitu satu action research yang dilakukan di kelas. Dari segi semantik (arti kata) action researh diterjemahkan menjadi penelitian tindakan. Carr dan Kemmis (McNiff, J, 1991, p.2) mendefisikan action research sebagai berikut: Action research is a form of self refflective enquiry undertaken by participants (teachers, students or principals, for example) in social (including educational) situations in order to improve the rationality and justice of (a) their own social or educational practices, (b) their understanding of these practices, and the situations (and institutions) in which the practices are carried out.

Berdasarkan definisi di atas terdapat beberapa ide pokok antara lain:

1. Penelitian Tindakan Kelas merupakan satu bentuk inkuiri atau penyelidikan yang dilakukan melalui refleksi diri

2. Penelitian Tindakan dilakukan oleh peserta yang terlibat dalam situasi yang diteliti, seperti guru, siswa, atau kepala sekolah.

3. Penelitian Tindakan dilakukan dalam situasi sosial, termasuk situasi pendidikan

4. Tujuan Penelitian Tindakan adalah untuk memperbaiki : dasar pemikiran dan kepantasan dari praktek-praktek, pemahamn terhadap praktek tersebut, serta situasi atau lembaga tempat tersebut dilaksanakan

Dari keempat ide pokok di atas, dapat ditarik kesimpulan bahwa Penelitian Tindakan Kelas merupakan penelitian dalam bidang sosial, yang menggunakan refleksi diri sebagai metode utama dilakukan oleh orang yang terlibat di dalamnya, serta bertujuan untuk melakukan perbaikan dalam berbagai aspek. Berdasarkan pengertian tersebut maka Penelitian Tindakan Kelas yang dilakukan guru di dalam kelasnya melalui refleksi diri, dengan tujuan untuk memperbaiki kinerjanya sebagai guru, sehingga hasil belajar siswa menjadi meningkat.

\section{B. Model Pembelajaran Interaktif}

Secara khusus, istilah model diartikan sebagai kerangka konseptual yang digunakan sebagai pedoman dalam melakukan suatu kegiatn. Sunarwan (1991) dalam Sobry Sutikno (2004:15) mengartikan model merupakan gambaran tentang keadaan nyata. Model pembelajaran atau model mengajar sebagai suatu rencana atau pola yang digunakan dalam mengatur materi pelajaran, dan memberi petunjuk kepada mengajar di kelas dalam setting pengajaran. Model pembelajaran merupakan kerangka konseptual yang melukiskan prosedur yang sistematis dalam mengorganisasikan pengalaman belajar untuk mencapai tujuan belajar tertentu dan berfungsi sebagai pedoman bagi para perancang pembelajaran dan para pengajar dalam merencanakan dan melaksanakan aktivitas belajar mengajar.

Model pembelajaran interaktif sering dikenal dengan nama pendekatan pertanyaan anak. Model ini dirancang agar siswa akan bertanya dan kemudian menemukan jawaban pertanyaan mereka sendiri (Faire \& Cosgrove dalam Harlen, 1992). Meskipun anak-anak mengajukan pertanyaan dalam kegiatan bebas, pertanyaan-pertanyaan tersebut akan terlalu melebar dan seringkali kabur sehingga kurang terfokus. Guru perlu mengambil langkah khusus untuk mengumpulkan, memilah, dan mengubah pertanyaan-pertanyaan tersebut ke dalam kegiatan khusus. Pembelajaran interaktif merinci langkah-langkah ini dan menampilkan suatu struktur untuk suatu pelajaran IPA yang melibatkan pengumpulan dan pertimbangan terhadap pertanyaan-pertanyaan siswa sebagai pusatnya (Harlen, 1992:48-50).

Model pembelajaran interaktif memiliki lima langkah. Langkah-langkah penerapan model pembelajaran Interaktif diawali dengan (1) persiapan, sebelum pembelajaran dimulai guru menugaskan siswa untuk membawa hewan peliharaannya dan mempersiapkan diri untuk menceritakan tentang hewan peliharaannya masing-masing. (2) kegiatan penjelajahan, pada saat pembelajaran di kelas siswa lain boleh mengamati hewan-hewan peliharaan teman-temannya dari dekat (meraba, 
mengelus, menggendong) dan mereka boleh mengajukan pertanyaan. (3) pertanyaan siswa diarahkan guru sekitar proses pemeliharaannya. penyelidikan, guru dan siswa memilih pertanyaan untuk dieksplorasi lebih jauh. Misalnya siswa diminta mengamati keadaan hewan-hewan yang tidak dipelihara, seperti dari mana mereka memperoleh makanannya, dimana mereka tidur, punya nama atau tidak, bagaimana kebersihannya. (5) refleksi, pada pertemuan berikutnya di kelas dibahas hasil penyelidikan mereka, dilakukan pembandingan antara hewan peliharaan dengan hewan liar untuk memantapkan hal-hal yang sudah jelas dan memisahkan hal-hal yang masih perlu diselidiki lebih jauh. Pada akhir kegiatan guru dapat memberikan tugas kepada siswa untuk mengamati bendabenda di sekitar siswa untuk mengamati benda-benda di sekitar mereka seperti buku dan tas sekolahnya.

Salah satu kebaikan dari model pembelajaran interaktif adalah bahwa siswa belajar mengajukan pertanyaan, mencoba merumuskan pertanyaan, dan mencoba menemukan jawaban terhadap pertanyaannya sendiri dengan melakukan kegiatan observasi (penyelidikan). Dengan cara seperti itu siswa atau anak menjadi kritis dan aktif belajar.

\section{Kerja Kelompok}

Suatu strategi pembelajaran untuk mencapai tujuan IPA yang berupaya untuk meningkatkan kemampuan siswa dalam bekerja sama, berpikir kritis, dan pada saat yang sama meningkatkan prestasi akademiknya. Disamping itu kerja kelompok dapat membantu siswa memahami konsep-konsep yang sulit sambil pada saat yang bersamaan sangat berguna untuk menumbuhkan kemauan kerja sama dan kemauan membantu teman. Kerja kelompok memungkinkan siswa lebih terlibat secara aktif dalam belajar karena ia mempunyai tanggung jawab belajar yang lebih besar dan memungkinkan berkembangnya daya kreatif dan sifat kepemimpinan pada siswa. Sedangkan peran guru lebih ditekankan sebagai organisator kegiatan belajar-mengajar, sumber informasi bagi siswa, pendorong bagi siswa untuk belajar, serta penyedia materidan kesempatan belajar bagi siswa. Guru harus dapat mendiagnosa kesulitan siswa dalam belajar dan dapat memberikan bantuan kepadanya sesuai dengan kebutuhannya.

\section{Pengertian Belajar}

Belajar merupakan salah satu bentuk perilaku yang amat penting bagi kelangsungan hidup manusia. Belajar membantu manusia menyesuaikan diri (adaptasi) dengan lingkungannya. Dengan adanya proses belajar inilah manusia bertahan hidup (survived). Belajar secara sederhana dikatakan sebagai proses perubahan dari belum mampu menjadi sudah mampu, tejadi dalam jangka waktu waktu tertentu. Perubahan yang itu harus secara relative bersifat menetap (permanent) dan tidak hanya terjadi pada perilaku yang saat ini nampak (immediate behavior) tetapi juga pada perilaku yang mungkin terjadi di masa mendatang (potential behavior). Hal lain yang perlu diperhatikan ialah bahwa perubahan-perubahan tersebut terjadi karena pengalaman. Perubahan yang terjadi karena pengalaman ini membedakan dengan perubahanperubahan lain yang disebabkan oleh kemasakan (kematangan).

\section{E. Kreativitas}

Dewasa ini istilah kreativitas atau daya cipta sering digunakan dalam kegiatan manusia sehari-hari, sering pula ditekankan pentingnya pengembangan kreativitas baik pada anak didik, pegawai negeri maupun pada mereka yang berwiraswasta. Kreativitas biasanya diartikan sebagai kemampuan untuk menciptakan suatu produk baru. Ciptaan itu tidak perlu seluruh produknya harus baru, mungkin saja gabungannya, kombinasinya, sedangkan unsurunsurnya sudah ada sebelumnya, kombinasi baru, atau melihat hubunganhubungan baru antara unsur, data, atau hal-hal yang sudah ada sebelumnya.

Kreativitas terletak pada kemampuan untuk melihat asosiasi antara hal-hal atau obyek-obyek yang sebelumnya tidak ada atau tidak tampak hubungannya. Seorang anak kecil asyik bermain dengan balokbalok yang mempunyai bentuk dan warna yang bermacam-macam, setiap kali dapat 
menyusun sesuatu yang baru, artinya baru bagi dirinya karena sebelumnya ia belum pernah membuat hal yang semacam itu. Anak ini adalah anak yang kreatif, berbeda dengan anak lain yang hanya membangun sesuatu jika ada contohnya.

Mengembangkan kreativitas dalam pembelajaran, Gordon dalam Joice and Weill (1996) dalam E. Mulyana (2005 : 163) mengemukakan empat prinsip dasar sinektik tentang kraetivitas. Pertama, kreativitas merupakan sesuatu yang penting dalam kegiatan sehari-hari. Hampir semua manusia berhubungan dengan proses kreativitas, yang dikembangkan melalui seni atau penemuan-penemuan baru. Lebih jauh Gordon menekankan bahwa kreativitas merupakan bagian dari kehidupan kita sehari-hari dan berlangsung sepanjang hayat. Kedua, proses kreatif bukanlah sesuatu yang misterius. Hal tersebut dapat diekspresikan dan mungkin membantu orang secara langsung untuk meningkatkan kreativitasnya. Secara tradisional, kreativitas didorong pleh kesadaran yang memberi petunjuk untuk mendeskripsikan dan menciptakan prosedur latihan yang dapat diterapkan di sekolah atau lingkungan lain. Ketiga, penemuan kreatif sama dalam semua bidang, baik dalam bidang seni, ilmu, maupun dalam rekayasa. Selain itu, penemuan kreatif ditandai oleh beberapa proses intelektual. Keempat, berpikir kraetif baik secara individu maupun kelompok adalah sama. Individu dan kelompok menurunkan ide-ide dan produk dalam berbagai hal.

\section{PELAKSANAAN PENELITIAN}

Penelitian dilaksanakan di kelas lima SDN Jakarta Timur pada Tahun Ajaran 2004/2005.

\section{A. Desain Penelitian}

Penelitian ini merupakan Penelitian Tindakan Kelas (Classroom Action Research) yang dilaksanakan dengan mengikuti prosedur penelitian berdasarkan pada prinsip Kemmis S, MC Toggar R (1988) yang mencakup kegiatan perencanaan (planning), tindakan (action), observasi (observation), refleksi (reflection) atau evaluasi. Keempat kegiatan ini berlangsung secara berulang dalam bentuk siklus. Penelitian ini dilakukan dengan cara berkolaborasi antara dosen LPTK (FKIP-UT) dengan guru SD N Jakarta Timur.

\section{B. Prosedur Penelitian}

Penelitian Tindakan Kelas ini terdiri atas tiga siklus kegiatan sebagai berikut.

\section{SIKLUS I}

Tahap Perencanaan (Planning)

1. Mengidentifikasi masalah

2. Menganalisis dan merumuskan masalah

3. Merancang model Pembelajaran interaktif

4. Mendiskusikan penerapan model pembelajaran interaktif

5. Menyiapkan instrumen (angket, pedoman observasi, tes akhir)

6. Menyusun kelompok belajar siswa

7. Merencanakan tugas kelompok

Tahap Melakukan Tindakan (Action)

1. Melaksanakan langkah-langkah sesuai perencanaan

2. Menerapkan model pembelajaran interaktif

3. Melakukan pengamatan terhadap setiap langkah-langkah kegiatan sesuai rencana

4. Memperhatikan alokasi waktu yang ada dengan banyaknya kegiatan yang dilaksanakan

5. Mengantisipasi dengan melakukan solusi apabila menemui kendala saat melakukan tahap tindakan

\section{Tahap Mengamati (observasi)}

1. Melakukan diskusi dengan guru SD dan kepala Sekolah untuk rencana observasi

2. Melakukan pengamatan terhadap penerapan model pembelajaran interaktif yang dilakukan guru kelas lima

3. Mencatat setiap kegiatan dan perubahan yang terjadi saat penerapan model pembelajaran interaktif

4. Melakukan diskusi dengan guru untuk membahas tentang kelamahankelemahan atau kekurangan yang dilakukan guru serta memberikan saran perbaikan untuk pembelajaran berikutnya 
Tahap refleksi (Reflection)

1. Menganalisis temuan saat melakukan observasi pelaksanaan observasi

2. Menganalisis kelemahan dan keberhasilan guru saat menerapkan model pembelajaran interaktif dengan kerja kelompok dan mempertimbangkan langkah selanjutnya

3. Melakukan refleksi terhadap penerapan model pembelajaran interaktif dengan kerja kelompok

4. Melakukan refleksi terhada kreativitas siswa dalam pembelajaran IPA

5. Melakukan refleksi terhadap hasil belajar siswa

\section{SIKLUS II}

\section{Tahap Refleksi/Siklus II meliputi:}

\section{Tahap Perencanaan (Planning)}

1. Hasil refleksi dievaluasi, didiskusikan, dan mencari upaya perbaikan untuk diterapkan pada pembelajaran berikutnya

2. Mendata masalah dan kendala yang dihadapi saat pembelajaran

3. Merancang perbaikan II berdasarkan refleksi siklus I

\section{Tahap Melakukan Tindakan (Action)}

1. Melakukan analisis pemecahan masalah

2. Melaksanakan tindakan perbaikan II dengan memaksimalkan penerapan model pembelajaran interaktif dengan kerja kelompok

\section{Tahap Mengamati (observation)}

1. Melakukan pengamatan terhadap penerapan model pembelajaran interaktif dengan kerja kelompok

2. Mencatat perubahan yang terjadi

3. Melakukan diskusi membahas masalah yang dihadapi saat pembelajaran dan memberikan balikan

\section{Tahap Refleksi (Reflection)}

1. Merefleksi proses pebelajaran interakti dengan kerja kelompok

2. Merfleksi hasil belajar siswa dengan penerapan model pembelajaran interaktif dengan kerja kelompok

3. Menganalisis temuan dan hasil akhir penelitian

4. Rekomendasi
Dari tahap kegiatan pada siklus I dan II, hasil yang diharapkan adalah

1) Siswa memiliki kemampuan dan kreativitas serta selalu aktif terlibat dalam proses pembelajaran IPA

2) Guru memiliki kemampuan guru merancang dan menerapkan model pembelajaran interaktif dengan kerja kelompok khusus pada mata pelajaran IPA

3) Terjadi peningkatan prestasi siswa pada mata pelajaran IPA

\section{Analisis Data}

Untuk lebih menjamin keakuratan data penelitian dilakukan perekaman data dalam video. Data yang diperoleh dianalisis dan dideskripsikan sesuai permasalahan yang ada dalam bentuk laporan hasil penelitian. Rancangan pembelajaran interaktif dan pemberian tugas kerja kelompok dilakukan validasi oleh teman sejawat dan kepala sekolah. Untuk kreativitas siswa dalam pembelajaran digunakan observasi dan angket serta perolehan hasil belajar siswa digunakan deskripsi kuantitatif.

\section{HASIL DAN PEMBAHASAN}

\section{SIKLUS I}

\section{Tahap Perencanaan (Planning)}

- Guru mulai mengidentifikasi masalah yang mungkin muncul saat pelaksanaan pembelajaran

- Guru mencoba menganilisis dan merumuskan masalah yang mungkin muncul saat pembelajaran

- Guru merancang model pembelajaran interaktif, dibantu peneliti

- Guru dan peneliti melakukan diskusi mengenai penerapan model pembelajaran interaktif, terutama langkah-langkah kegiatan diskusi kelompok siswa

- Peneliti dan guru bersama-sama membuat angket untuk siswa dan pedoman observasi

- Guru menyusun kelompok berdasarkan siswa yang pandai dibagi merata kesetiap kelompok

- Guru merencanakan tugas kelompok tentang topik/materi IPA/Sains 
Tahap Melakukan Tindakan (Action)

- Guru melaksanakan langkah-langkah kegiatan sesuai perencanaan pembelajaran

- Guru menerapkan model pembelajaran interaktif pada pelajaran Sains/IPA

- Peneliti dan pengamat (teman sejawat dan kepala sekolah) melakukan pengamatan terhadap setiap langkahlangkah kegiatan sesuai rencana

- Peneliti dan pengamat memperhatikan alokasi waktu yang ada dengan banyaknya kegiatan yang dilaksanakan

- Guru belum dapat mengantisipasi kendala dengan melakukan solusi mengalami kendala saat melakukan tahap tindakan

Tahap Mengamati (observasi)

- Peneliti, pengamat (teman sejawat dan kepala sekolah) dan guru melakukan diskusi untuk rencana observasi pada pembelajaran IPA/Sains berikutnya

- Peneliti dan para pengamat melakukan pengamatan terhadap penerapan model pembelajaran interaktif yang dilakukan guru

- Peneliti dan para pengamat mencatat setiap kegiatan dan perubahan yang terjadi saat penerapan model pembelajaran interaktif. Pada awal pembelajaran guru melaksanakan pembelajaran sesuai dengan prncanaan, namun setelah beberapa saat guru kembali kepada pola lama yang biasa dilakukan dalam pembelajaran yaitu menjelaskan materi dan siswa menyimak penjelasan guru dan mencatat hal yang dianggap penting. Guru nampak tidak percaya diri ketika siswa bertanya tentang materi yang tidak dimengerti ketika mengerjakan tugas di rumah.

- Peneliti, para pengamat dan guru melakukan diskusi untuk membahas tentang kelemahan-kelemahan atau kekurangan yang dilakukan guru serta memberikan saran perbaikan untuk pembelajaran IPA/Sains berikutnya. Saran yang diberikan peneliti dan juga para pengamat salah satunya adalah guru harus membaca materi IPA/Sains paket, meskipun guru sudah sering mengajarkan materi tersebut. Guru juga harus membaca beberapa buku referensi lain selain buku paket dan buku wajib, agar guru lebih percaya diri dan dapat menjawab semua pertanyaan siswa dengan tepat. Guru harus dapat mengalokasi waktu dengan baik, sehingga dapat merangkum materi yang dibahas.

\section{Tahap refleksi (Reflection)}

- Guru menlakukan analisis temuan peneliti dan para pengamatan saat melakukan observasi pelaksanaan pembelajaran oleh guru

- Peneliti dan para pengamat menganalisis kelemahan dan keberhasilan guru saat menerapkan model pembelajaran interaktif dan mempertimbangkan langkah selanjutnya. Terutama dalam mengelola kelas, saat siswa melakukan kerja kelompok.

- Guru melakukan refleksi terhadap penerapan model pembelajaran interaktif pada pelajaran IPA/Sains. Selama diskusi kelas guru berusaha berkeliling pada setiap kelompok. Guru menanyakan kesulitan atau masalah yang dihadapi saat melakukan percobaan.

- Guru dibantu peneliti melakukan refleksi terhadap kreativitas siswa dalam pembelajaran IPA/Sains, di samping itu guru mengadakan evaluasi tentang topik yang sudah dibahas dan nilai rata-rata siswa 5,859. Kreativitas meningkat setelah mengalami pembelajaran yang dilaksanakan guru. Siswa terlibat aktif dalam diksusi kelompok dan percobaan.

- Guru melakukan refleksi terhadap hasil belajar siswa, mengevaluasi terhadap kekurangan dan kelemahannya dalam pelaksanaan pembelajaran, berupaya untuk memperbaikinya.

\section{SIKLUS II}

Tahap Refleksi/Siklus II meliputi:

\section{Tahap Perencanaan (Planning)}

- Hasil refleksi guru dievaluasi dan didiskusikan bersama dengan peneliti dan para pengamat dan mencari upaya perbaikan untuk diterapkan pada pembelajaran IPA/Sains berikutnya.

- Guru mendata masalah-masalah dan kendala yang dihadapi saat pembelajaran

- Guru merancang perbaikan pembelajaran berdasarkan refleksi siklus I

\section{Tahap Melakukan Tindakan (Action)}

- Guru melakukan analisis dan pemecahan masalah yang dihadapinya dalam pelaksanaan pembelajaran

- Guru melaksanakan tindakan perbaikan 
pembelajaran dengan memaksimalkan penerapan model pembelajaran interaktif dan berusaha memperbaiki kekurangan dan kelemahan saat pembelajaran.

\section{Tahap Mengamati (observation)}

- Peneliti dan para pengamat melakukan pengamatan terhadap penerapan model pembelajaran interaktif

- Peneliti dan para pengamat mencatat perubahan yang terjadi, guru lebih percaya diri dan menjelaskan materi/ konsep dengan baik. Guru sudah dapat berperan sebagai nara sumber, fasilitator dan mediator dengan baik. Guru sudah dapat mengelola kelas dengan baik.

- Guru, peneliti dan para pengamat melakukan diskusi membahas masalah yang dihadapi saat pembelajaran dan memberikan balikan.

\section{Tahap Refleksi (Reflection)}

- Guru merefleksi proses pembelajaran interaktif yang dilaksanakannya

- Guru merefleksi hasil belajar siswa dengan penerapan model pembelajaran interaktif

- Guru menganalisis temuan dan hasil akhir penelitian

- Peneliti dan guru memberikan rekomendasi terhadap hasil akhir penelitian tindakan kelas yang dilakukan guru.

Dari tahap kegiatan pada siklus I dan II, hasil yang diharapkan adalah

- Siswa memiliki kemampuan dan kreativitas serta selalu aktif terlibat dalam proses pembelajaran IPA. Setiap pembelajaran IPA siswa selalu sudah siap dengan pertanyaan tentang materi/topik yang akan dibahas. Siswa sudah terbiasa bekerja kelompok dan berdiskusi

- Guru telah memiliki kemampuan merancang dan menerapkan model pembelajaran interaktif khususnya pada mata pelajaran IPA/Sains. Ada kemauan guru untuk menerapkan model pembelajaran interaktif pada pelajaran lainnya

- Prestasi siswa dalam pelajaran IPA/Sains meningkat. Nilai rata siswa mencapai 6,512

\section{KESIMPULAN DAN SARAN}

\section{A. Kesimpulan}

- Guru dalam mendesain model pembelajaran interaktif untuk mata pelajaran IPA, pada awalnya masih ragu dan belum terbiasa.

- Guru dalam menerapkan model pembelajaran interaktif pada mata pelajaran IPA di SD dengan kerja kelompok. Pada awalnya siswa mengalami kesulitan bekerja dalam kelompok, terutama siswa yang pintar/pandai tidak mau bergabung dengan siswa yang tidak/kurang pandai. Siswa yang merasa dirinya pandai lebih suka belajar dan bekerja sendiri. Siswa terkesan egois, untuk dapat menyatukan siswa dalam kelompok dan bekerja sama guru berusaha memberi penjelasan tentang pentingnya berbagi, bekerja sama, bersahabat tanpa memperhatikan kepintaran atau kemampuan orang lain. Justru siswa yang memiliki kelebihan daripada teman-temannya dapat membantunya dengan memberikan penjelasan tentang teori/materi pelajaran yang belum dipahami dan dimengerti

- Kinerja belajar siswa meningkat setelah pembelajaran IPA menggunakan model pembelajaran interaktif. Siswa sangat antusias membahas topik dalam diskusi, dan berusaha menjawab dan menemukan informasi tentang topik tersebut. Siswa saling berebut mengemukakan informasi (apa yang mereka ketahui) tentang topik. Setelah dilakukan pembagian tugas kelompok siswa bekerja sesuai dengan tugasnya masing-masing.

- Guru dalam menerapkan model pembelajaran interaktif dengan kerja kelompok, mengalami kesulitan dalam pengelolaan waktu. Guru belum dapat membagi waktu dalam masing-masing kegiatan pembelajaran. Siswa terlalu melakukan diskusi, sehingga guru tidak sempat merangkum/ menyimpulkan materi yang dibahas karena waktunya sudah habis.

- Prestasi belajar siswa meningkat setelah mengalami pembelajaran interaktif dengan kerja kelompok. 
Pada siklus pertama nilai rata-rata siswa perorangan 5,859; nilaia ratarata kelompok sebesar 6,102. Pada siklus kedua nilai rata-rata siswa 6,512 dan nilai rata-rata kelompok 7,615; sedangkan pada siklus ketiga nilai rata-rata siswa 7,948 dan nilai rata-rata kelompok 7,384. Berdasarkan nilai yang diperoleh siswa dapat disimpulkan bahwa model pembelajaran interaktif dengan kerja kelompok dapat digunakan pada penelitian tindakan kelas.

- Penelitian tindakan kelas yang dilakukan bertujuan adalah memperbaiki pembelajaran yang dilaksanakan guru. Menggunakan model pembelajaran interaktif dengan kerja kelompok dapat dijadikan alternatif untuk penelitian tindakan kelas yang akan dilaksanakan berikutnya.

\section{B. Saran}

Penerapan model pembelajaran interaktif dengan kerja kelompok memerlukan kemauan dan pengorbanan yang besar, baik waktu, tenaga dan pikiran untuk itu bagi guru sekolah dasar mampu melaksanakan penelitian tindakan kelas menggunakan model pembelajaran ini sebagai suatu tantangan.

Penelitian tindakan kelas sebaiknya dilakukan oleh guru dengan penuh kesadaran dan tanggung jawabnya sebagai pendidik, peneliti hanya berusaha menjembatani dan memfasilitasi agar para guru sekolah dasar mau melakukan penelitian tindakan kelas sebagai langkah introspeksi diri sebagai tenaga profesional.

Sebaiknya penelitian tindakan kelas dilakukan oleh semua guru, baik guru SD, SMP, maupun SMA, sebagai upaya untuk meningkatkan kinerja sebagai guru. Guru harus dapat menilai dirinya sendiri sebelum melakukan penilaian kepada siswanya. Guru harus mengetahui kelemahan dan kekurangannya dalam pembelajarannya, berusaha untuk mengatasinya dan menemukan solusi yang terbaik serta mengantisipasi apabila dalam pembelajaran mengalami kendala dan masalah.

\section{DAFTAR PUSTAKA}

Arifin, Zainal. (1994). Pendekatan Dalam Proses Belajar Mengajar. Remaja Rosdakarya. Bandung.

Gagne, R.M (1985). The Conditions of Learning Theory of instruction (4 ${ }^{\text {th }}$ Edition). New York: Holt, Rinehart and Winston.

Hasibuan, J.J, Mudjiono (1988), Proses Belajar Mengajar. CV. Remaja Karya. Bandung.

Hendro Darmodjo, Kaligis, J R E. (1991/1992). Pendidikan IPA II, Hal 7-11 Depdikbud Dirjen Dikti, Proyek Pembinaan Tenaga Kependidikan

Hernawaty Damanik. (2004). Penerapan Model Pembelajaran Social Science Inquiry Dalam Mata Pelajaran Sosiologi Dengan Kerja Kelompok. FKIP- Universitas Terbuka.

Irwanto, dkk (1991). Psikologi Umum Buku Panduan Mahasiswa. Gramedia Pustaka Utama. Jakarta.

Kemmis, S. dan MC. Toggart.R. (Ed.1988). The Action Resesarch Planner. Deakin. Deakin University: Australia

Lemlit-UT, (2003). Jurnal Pendidikan Volume 4, nomor 2. Pusat Studi Lembaga Penelitian Universitas Terbuka.

Mulyasa, E (2005). Menjadi Guru Profesional : Menciptakan Pembelajaran Kreatif dan Menyenangkan. Remaja Rosdakarya. Bandung.

Poedjiadi, A. (1990). Pendidikan Sains dan Teknologi di Masa yang akan datang. Disampaikan pada Seminar Puskur Balitbang Dikbud, Jakarta.

Poedjiadi, A. (1993). Mewujudkan literasi Sains dan Teknologi Melalui Pendidikan, hal 4-6. Disampaikan pada seminar FPMIPA IKIPBandung.

Slavin, RE.(1994). Educational Psychology : Theory and Practice. Masschusetts: Allyn and Bacon Publisher.

Sobry Sutikno, (2004). Model Pembelajaran Interaksi Sosial, Pembelajaran Efektif dan Retorika. NTP Press. Mataram

Slavin, RE.(1994). Educational Psychology : Theory Research and Practice. Second Edition. Boston: Allyn and Bacon.

Sutarno, N. (2004). Materi Dan Pembelajaran IPA SD. Pusat Penerbitan Universitas Terbuka. 